\title{
PELATIHAN PENYUSUNAN KONTRAK JUAL BELI BAGI UMKM DI DESA MANGUNGJAYA DAN DESA SUKANAGALIH KECAMATAN RAJAPOLAH KABUPATEN TASIKMALAYA DALAM RANGKA MENUNJANG KEGIATAN PEREKONOMIAN MASYARAKAT
}

\author{
Suwandono, A., Faisal, P. dan Zamil, Y.S. \\ Fakultas Hukum Universitas Padjadjaran \\ E-mail: suwandono49@gmail.com
}

\begin{abstract}
ABSTRAK
Permasalahan hukum yang terjadi dalam suatu kontrak jual beli sangat merugikan para pihak dalam dunia bisnis. Pengetahuan dan keterampilan dalam membuat suatu kontrak jual beli harus dimiliki oleh para pelaku usaha sehinga dapat menghindari kesalahan dan meminimalisir sengketa yang timbul dari suatu kontrak. Dalam suatu kegiatan bisnis diperlukan suatu kontrak yang baik dan benar dalam rangka memberikan kepastian hukum bagi para pihak. Metode yang digunakan dalam kegiatan ini berupa pelatihan, yang diawali dengan ceramah, praktik penyusunan kontrak, dilanjutkan dengan tanya jawab dengan peserta pelatihan. Melalui ceramah disampaikan materi mengenai hukum kontrak dan penyusunan kontrak. Praktik penyusunan kontrak dilaksanakan dengan bantuan isntruktur. Tanya jawab dapat melengkapi materi yang belum jelas serta menyelesaikan permasalahan yang dihadapi oleh warga masyarakat. Pelatihan penyusunan kontrak jual beli itu dilaksanakan dalam rangka meningkatkan pengetahuan dan keterampilan dalam menyusun suatu kontrak jual beli. Dengan meningkatnya pengetahuan dan keterampilan ini, UMKM/ masyarakat dapat menyusun kontrak jual beli dengan baik dan benar sehingga dapat menghindari kesalahan-kesalahan dalam penyusunan kontrak jual beli serta memberikan kepasian hukum kepada para pihak sehingga dapat membantu menunjang kegiatan perekonomian masyarakat.
\end{abstract}

Kata kunci : pelatihan, kontrak, jual beli.

\section{ABSTRACT}

Legal issues in a contract of sale is very detrimental to the parties in the business world. Knowledge and skills in making a purchase contract must be owned by the business, so that we can avoid mistakes and minimize disputes arising from a contract. It is given that in a business activity requires a contract that is good and right in order to provide legal certainty for the parties. The method used in this activity in the form of training, which begins with a lecture, contracting practices, followed by questions and answers with participants. Through lectures, delivered materials on contract law and contract drafting. Contracting practices implemented with the help of isntruktur. As for the question and answer can complete through the material is not yet clear and resolve problems faced by citizens. Training preparation purchase agreement is implemented in order to improve knowledge and skills in preparing a purchase contract. With increasing knowledge and skills, SMEs / communities can draw up the contract of sale properly so as to avoid errors in preparing the sales contract, as well as providing legal kepasian to the parties, so as to help support the community's economy.

Key words : training, contracts, buying and selling .

\section{PENDAHULUAN}

Kecamatan Rajapolah merupakan salah satu sentra perekonomian di Kabupaten Tasikmalaya, yakni merupakan sentra industri kerajinan. Produk kerajinan yang dijual antara lain anyaman pandang, makanan olahan, tas wanita dan anyaman mendong box file. Industri kerajinan di Rajapolah pada umumnya merupakan produk/ buatan dari masyarakat di sekitar Rajapolah, yakni dari desa-desa yang berada di Rajapolah, antara lain Desa Manggungjawa dan Desa Sukanagalih. Selain itu, kegiatan perekonomian di Rajapolah juga didukung oleh bidang-bidang lainnya, yakni bidang pertanian (padi, jamur tiram), pedagang, peternakan (ayam broiler, itik).

Masyarakat Desa Manggungjaya dan Desa Sukanagalih dalam menjalankan kegiatan usahanya, selalu berinteraksi dengan pihak lain untuk memasarkan hasil usahanya, misalnya dengan konsumen atau pelaku usaha lainnya (tengkulak, pedagang besar atau eksportir). Kegaitan memasarkan hasil usaha itu dituangkan dalam suatu kontrak jual beli, sehingga penyusunan suatu kontrak jual beli haruslah benar agar menghindari kesalahan atau kendala-kendala dalam pelaksanaan kontrak.

Penyusunan kontrak haruslah sesuai dengan ketentuan Buku III KUH Perdata, antara lain mengenai syarat sahnya perjanjian, yang jika syarat sahnya perjanjian itu tidak dipenuhi konsekuensi hukumnya adalah perjanjian tersebut dapat dibatalkan atau batal demi hukum. Selain itu, yang penting juga dalam suatu kontrak ialah penyusunan isi atau klausul-klausul perjanjian, yang di dalamnya diatur antara lain mengenai hak dan kewajiban para pihak, overmacht, dan penyelesaian sengketa. Kombinasi antara kedua hal itu haruslah diperhatikan dalam suatu penyusunan suatu kontrak, sehingga dapat memperkecil kesalahan/ kendala serta memberikan kepastian hukum bagi para pihak dalam menjalankan kegitan usahanya. Pengetahuan dan kemampuan untuk menyusun kontrak jual beli itu diharapkan dapat menunjang kegiatan ekonomi masyarakat.

\section{SUMBER INSPIRASI}

Pengetahuan hukum tentang hukum perjanjian pada umumnya serta keterampilan dalam penyusunan kontrak merupakan salah satu aspek penting yang harus dimiliki oleh seseorang atau kelompok dalam kegiatan bisnis atau ekonomi. Salah satu kegiatan yang dilakukan adalah transaksi jual beli baik yang dilakukan dengan konsumen atau dengan sesama pelaku usaha. Suatu kontrak pada dasarnya memuat hak dan kewajiban bagi para pihak sehingga untuk memberikan kepastian hukum bagi para pihak, suatu kontrak harus disusun secara baik dan benar 
sehinga dapat terhindari dari kesalahan dan itu dapat memperkecil sengketa yang timbul dari suatu kontrak. Salah satu cara yang dapat dilakukan dalam rangka meninggkatkan pengetahuan dan keterampilan dalam menyusun suatu kontrak yang baik dan benar yakni dengan memberikan pelatihan bagi anggota masyarakat.

\section{METODE}

Metode yang digunakan dalam kegiatan ini berupa pelatihan, yang diawali dengan ceramah, praktik penyusunan kontrak, dilanjutkan dengan tanya jawab dengan peserta pelatihan. Melalui ceramah, disampaikan materi mengenai hukum kontrak dan penyusunan kontrak. Praktik penyusunan kontrak dilaksanakan dengan bantuan isntruktur. Tanya jawab dapat melengkapi materi yang belum jelas serta menyelesaikan permasalahan yang dihadapi oleh warga masyarakat.

\section{KARYA UTAMA}

Perjanjian diatur dalam Buku III Kitab Undang-Undang Hukum Perdata (KUH Perdata) Tentang Perikatan. Sistem Pengaturan Buku III KUH Perdata bersifat terbuka, yakni setiap orang diberikan kebebasan untuk membuat suatu perjanjian baik yang sudah diatur dalam UU maupun yang belum diatur dalam suatu undang-undang asal tidak bertentangan dengan UU, ketertiban umum atau kesusilaan.

Pasal 1313 KUH Perdata menyatakan bahwa perjanjian adalah suatu perbuatan yang dengannya satu orang atau lebih mengikatkan dirinya terhadap satu orang atau lebih. Pengertian Perjanjian Pasal 1313 KUH Perdata tersebut tidak lengkap dan terlalu luas (Setiawan, 1977) sehingga rumusan perjanjian disempurnakan yakni perjanjian adalah suatu hubungan hukum antara dua orang atau lebih yang bersepakat/saling mengikatkan diri untuk menimbulkan akibat hukum. Menurut Mertokusomo, 1985 dalam setiap perjanjian terdapat tiga macam unsur-unsur, yaitu :

\section{Unsur essentialia}

Unsur essentialia ini adalah unsur yang mutlak harus ada dalam suatu perjanjian. Misalnya, dalam perjanjian jual beli harus ada harga dan barang.

\section{Unsur naturalia}

Unsur naturalia ialah unsur yang lazimnya melekat pada perjanjian, yaitu unsur yang tanpa diperjanjikan secara khusus atau tegas dalam perjanjian dengan sendiri dianggap ada dalam perjanjian. Dalam jual beli misalnya penjual harus menjamin tidak ada cacad tersembunyi.

\section{Unsur accidentalia}

Unsur accidentalia ialah unsur yang harus dimuat atau disebut secara tegas dalam perjanjian, misalnya identitas dan domisili.

Pasal 1320 KUH Perdata, menentukan syarat sahnya perjanjian, yaitu:
1. sepakat mereka yang mengikatkan diri;

2. cakap untuk membuat perjanjian;

3. mengenai suatu tertentu;

4. suatu sebab yang halal.

Dua syarat yang pertama dinamai syarat subyektif, karena kedua syarat tersebut mengenai orangorangnya atau subyek yang mengadakan perjanjian. Dua syarat yang terakhir merupakan syarat obyektif karena mengenai perjanjiannya sendiri atau obyek dari perbuatan hukum yang dilakukan itu. Dalam hal suatu syarat subyektif tidak terpenuhi, perjanjian itu dapat dibatalkan (vernietigbaar). Pihak yang dapat meminta pembatalan adalah pihak yang tidak cakap atau pihak yang memberikan sepakat secara tidak bebas. Perjanjian yang telah dibuat tersebut tetap mengikat, selama tidak dibatalkan (oleh hakim) atas permintaan pihak yang berhak meminta pembatalan tadi. Dalam hal syarat obyektif tidak terpenuhi, perjanjiannya adalah batal demi hukum (nietig), artinya bahwa secara yuridis dari semula tidak ada suatu perjanjian dan tidak ada pula suatu perikatan antara para pihak, karena itu salah satu pihak tidak dapat menuntut pihak yang lain di depan hakim, karena dasar hukumnya tidak ada. Syarat sahnya perjanjian di atas akan diuraikan satu per satu sebagai berikut:

a. sepakat mereka yang mengikatkan diri

Kata sepakat merupakan dasar lahirnya suatu perjanjian. Suatu perjanjian dianggap lahir atau terjadi pada saat dicapainya kata sepakat di antara para pihak yang mengadakan perjanjian. Kata sepakat mengandung pengertian bahwa para pihak saling mengutarakan kehendak masing-masing untuk membuat suatu perjanjian; kehendak pihak yang satu secara timbal balik sesuai dengan kehendak pihak yang lain. Berdasarkan Pasal 1321 KUH Perdata diharuskan ada kata sepakat yang bebas, artinya bahwa kata sepakat yang diperoleh bukan karena kekhilafan (dwaling), paksaan (dwang) dan penipuan (bedrog).

b. cakap untuk membuat perjanjian

Pasal 1329 KUH Perdata menyebutkan bahwa setiap orang adalah cakap untuk membuat perikatan-perikatan jika ia oleh undang-undang tidak dinyatakan tak cakap. Berdasarkan ketentuan itu diketahui bahwa pada umumnya setiap orang dianggap cakap untuk membuat perikatan, kecuali mereka secara tegas dianggap tidak cakap oleh undang-undang, yakni mereka yang belum dewasa dan orang yang ditaruh dalam pengampuan.

c. mengenai suatu hal tertentu

Suatu hal tertentu sebagai syarat ketiga syarat sahnya perjanjian mengandung pengertian bahwa apa yang diperjanjikan hak-hak dan kewajiban kedua belah pihak jika timbul suatu perselisihan. (Subekti, 2002) Hal tertentu dalam suatu perjanjian tertuju pada kebendaan (zaak) atau barang. Barang yang dimaksud dalam perjanjian paling tidak harus dapat ditentukan jenisnya, sebagaimana ditentukan dalam Pasal 1333 ayat (1) KUH Perdata, yaitu suatu perjanjian harus mempunyai sebagai pokok suatu barang yang paling sedikit ditentukan jenisnya. 
d. suatu sebab yang halal

Mengenai apa yang dimaksud dengan sebab (causa) dan causa yang halal, undang-undang tidak memberikan pengertian secara tegas, tetapi para sarjana sepakat bahwa causa di sini bukan merupakan sebab dalam arti lawan dari akibat. Menurut Subekti, 2002, sebab dalam suatu perjanjian adalah isi dari perjanjian itu sendiri. Suatu yang menyebabkan seorang membuat suatu perjanjian atau dorongan jiwa untuk membuat suatu perjanjian pada dasarnya tidak dipedulikan oleh undang-udang. KUH Perdata tidak secara tegas memberikan pengertian mengenai sebab yang halal. Pasal 1337 KUH Perdata hanya menyebutkan bahwa "suatu sebab adalah terlarang, apabila dilarang oleh undang-undang, atau apabila berlawanan dengan kesusilaan baik atau ketertiban umum".

Di dalam hukum perjanjian terdapat beberapa asas-asas hukum yang penting untuk dipahami, antara lain:

a. asas konsensualisme

konsensualisme berasal dari kata consensus yang berarti sepakat. Asas konsensualisme ini menentukan bahwa pada dasarnya perjanjian itu sudah dilahirkan sejak detik tercapainya kesepakatan. Dengan perkataan lain bahwa "perjanjian itu sudah terjadi apabila para pihak sudah sepakat mengenai hal-hal yang pokok dan tidaklah diperlukan sesuatu formalitas, misalnya dibuat secara tertulis, atau dengan akta notaris". (Subekti, 2002: 15)

b. asas kebebasan berkontrak

asas kebebasan berkontrak ini memungkinan setiap orang untuk membuat perjanjian apa pun baik yang sudah ada aturannya dalam undangundang maupun yang belum ada aturannya di dalam undang-undang. Asas kebebasan berkontrak dalam hukum perjanjian tidaklah mutlak sebebasbebasnya, namun ada batasannya. Batasan itu diberikan oleh Pasal 1337 KUH Perdata yang menentukan bahwa perjanjian tersebut tidak boleh bertentangan dengan undang-undang, ketertiban umum dan kesusilaan.

c. asas pacta sunt servenda

asas kekuatan mengikatnya perjanjian (pacta sunt servenda) berkaitan dengan akibat perjanjian. Asas itu tersimpul dari Pasal 1338 ayat (1) KUH Perdata dari kata-kata "berlaku sebagai undang-undang bagi mereka yang membuatnya". Asas pacta sunt servenda menentukan bahwa "kedua belah pihak terikat oleh kesepakatan dalam perjanjian yang mereka buat". Asas itu menentukan bahwa terhadap perjanjian yang dibuat secara sah; para pihak terikat untuk melaksanakan apa yang telah mereka sepakati sehingga perjanjian itu berlaku sebagai undang-undang.

d. asas itikad baik (goeder trouw) asas itikad baik berkaitan dengan pelaksanaan dari suatu perjanjian yang telah diadakan oleh para pihak, yaitu menghendaki agar suatu perjanjian harus dilaksanakan dengan itikad baik. Asas ini dapat disimpulkan dari ketentuan Pasal 1338 ayat (3) KUH Perdata yaitu bahwa "suatu perjanjian harus dilaksanakan dengan itikad baik". Maksud perjanjian harus dilaksanakan dengan itikad baik adalah perjanjian harus dilaksanakan dengan memperhatikan dan mematuhi norma-norma kepatutan.

e. asas kepribadian

asas kepribadian ini terdapat dalam Pasal 1315 KUH Perdata yang berbunyi "pada umumnya tak seorang pun dapat mengikatkan diri atas namanya sendiri atau meminta ditetapkannya suatu janji dari pada untuk dirinya sendiri". Makna dari asas itu adalah bahwa mengikatkan diri ditujukan pada memikul kewajiban-kewajiban atau menyanggupi melakukan sesuatu. Adapun minta ditetapkannya suatu janji ditujukan pada memperoleh hak-hak atas sesuatu atau dapat menuntut sesuatu. Hal itu sudah sewajarnya karena perikatan yang disebabkan oleh suatu perjanjian itu sendiri dan tidak mengikat pada orang lain. Dengan demikian, yang dilakukan hanya meletakkan hak dan kewajiban kepada pihak yang membuat perjanjian.

Perjanjian jual beli adalah suatu perjanjian bertimbal-balik yang di dalamnya pihak yang satu (si penjual) berjanji untuk menyerahkan hak milik atas suatu barang, sedang pihak yang lainnya (si pembeli) berjanji untuk membayar harga yang terdiri atas sejumlah uang sebagai imbalan dari perolehan hak milik. (Subekti, 1995: 1).

Unsur pokok atau unsur essentialia dari suatu perjanjian jual beli adalah adanya barang dan harga. Suatu perjanjian jual beli sudah dilahirkan pada detik tercapainya kesepakatan mengenai barang dan harga sehingga jika kedua belah pihak sudah setuju mengenai barang dan harga, lahirlah perjanjian jual beli itu. Hal itu sesuai dengan Pasal $1458 \mathrm{KUH}$ Perdata yang menyatakan bahwa jual beli sudah dianggap sah antara kedua belah pihak seketika setelah mereka mencapai sepakat tentang barang dan harga, meskipun barang itu belum diserahkan maupun harganya belum dibayar.

Suatu perjanjian jual beli yang telah sepakati menimbulkan hak dan kewajiban para pihak untuk dilaksanakan. Hak dan kewajiban para pihak (penjual dan pembeli) terdiri atas:

Bagi penjual ada dua kewajiban yang utama yakni :

a. menyerahkan hak milik atas barang yang diperjualbelikan. Kewajiban menyerahkan hak milik meliputi segala perbuatan yang menurut hukum diperlukan untuk mengalihkan hak milik atas barang yang diperjual-belikan itu dari si penjual kepada si pembeli.

b. menanggung kenikmatan tenteram atas barang tersebut dan menanggung terhadap cacad-cacad tersembunyi. Kewajiban untuk menanggung kenikmatan tenteram merupakan konsekuensi dari jaminan yang oleh penjual diberikan kepada pembeli bahwa barang yang dijual dan dialihkan itu adalah sungguh-sungguh miliknya sendiri yang bebas dari sesuatu beban atau tuntutan dari suatu pihak.

Kewajiban utama si pembeli ialah untuk membayar harga pembelian pada waktu dan di tempat sebagaimana ditetapkan menurut perjanjian. Jika pada 
waktu membuat perjanjian tidak ditetapkan tentang tempat dan waktu pembayaran, si pembeli harus membayar di tempat dan pada waktu penyerahan barang harus dilakukan.

Menurut Pasal 1459 KUH Perdata, Jual beli menurut ialah hanya suatu perjanjian "obligator" saja, artinya baru meletakkan hak dan kewajiban kepada kedua belah pihak, belum memindahkan hak milik. Sehingga untuk adanya peralihan hak milik, harus dilakukan penyerahan terhadap barang tersebut.

Pada umumnya anatomi suatu kontrak terdiri dari: (Frans Satrio Wicaksono, 2008: 35-55)

1. Judul (Heading). Judul suatu kontrak mencerminkan isi dari suatu kontrak, sehingga judul kotrak harus sesuai dengan isinya, contoh: 'Perjanjian Jual Beli Mobil'.

2. Pembukaan (Opening). Pembukaan merupakan permulaan dari suatu kontrak, yang memuat tempat dan tanggal pembuatan kontrak.

3. Komparisi (Parties). Komparisi merupakan bagian dari kontrak yang menyebutkan identitas para pihak yang membuat kontrak (nama, pekerjaan, tempat tinggal, dan lain-lain), termasuk uraian yang dapat menunjukkan bahwa para pihak tersebut mempunyai kecakapan (rechts bekwaamheid) serta kewenangan (rechts bevoegheid) untuk melakukan tindakan-tindakan hukum.

4. Premise (Recitals). Premise merupakan suatu pernyataan yang merupakan pertimbangan, latar belakang atau alasan dibuatnya suatu kontrak. Penulisannya dalam kontrak biasanya dimulai dengan kata "bahwa". Biasanya di sini disebutkan bidang usaha para pihak dan diakhiri dengan pernyataan kesepakatan antara para pihak.

5. Isi Perjanjian. Pada bagian ini para pihak mencantumkan segala hal atau pokok-pokok yang dianggap perlu, yang merupakan kehendak para pihak sebagai suatu pernyataan tertulis yang sah. Bagian itu mencakup dan mengandung semua isi perjanjian yang sekaligus merupakan isi perjanjian yang memuat secara mendetail mengenai objek perjanjian, hak dan kewajiban, serta uraian secara lengkap mengenai prestasi. Pembuatan isi pokok/ dalam menentukan judul tiap-tiap pasal perjanjian harus mengacu kepada jenis perjanjian yang akan dibuat.

6. Penutup (Closure). Suatu kontrak/perjanjian ditutup dengan kalimat yang menyatakan bahwa perjanjian dibuat dalam jumlah rangkap yang diperlukan dan bermaterai cukup. Apabila dalam pembukaan belum disebutkan waktu dan tempat kontrak/perjanjian itu dibuat, itu harus disebutkan dalam penutupan.

7. Tanda Tangan (Attestation). Dicantumkan tanda tangan para pihak atau yang mewakilinya dan tanda tangan para saksi. Apabila yang menjadi pihak dalam perjanjian adalah badan hukum, di bawah tanda tangan juga disebutkan nama dan jabatannya, dilengkapi dengan cap perusahaan di sebelah tanda tangan.

8. Saksi-Saksi (Witnesses). Suatu kontrak ditanda tangani 2 orang saaksi dalam perjanjian.

9. Lampiran (Attachments/Exhibits). Suatu kontrak/ perjanjian adakalanya disertai dengan lampiran apabila terdapat hal-hal yang perlu disertakan pada kontrak atau perjanjian itu, misalnya surat kuasa, daftar rincian barang dsn harga, gambar/ bagan, dan lain-lain.

\section{ULASAN KARYA}

Pelatihan penyusunan kontrak jual beli bagi UMKM dalam rangka menunjang kegiatan perekonomian masyarakat ini mendapatkan apresiasi yang cukup baik dari peserta pelatihan. Dialog interaktif terjadi antara instruktur dengan peserta berkaitan dengan permasalahan sehari-hari yang dialami oleh masyarakat. Pertanyaan-pertanyaan yang disampaikan oleh masyarakat kebanyakan mengenai kasus-kasus yang dialami oleh masyarakat.

Berikut pertanyaan-pertanyan peserta pelatihan, baik pada saat pelaksanaan praktik/ latihan penyusunan kontrak maupun pada saat sesi tanya jawab:

Pengaturan Hukum Perjanjian dalam Buku III KUH Perdata pada dasarnya bersifat mengatur dan melengkapi. Konsekuensinya adalah bahwa para pihak dapat mengesampingkan ketentuan yang diatur dalam KUH Perdata. Para pihak dapat mengatur berbeda (mengesampingkan aturan dalam KUH Perdata), jika para pihak bersepakat mengatur lain. Misalnya dalam perjanjian jual beli, KUH Perdata menentukan bahwa barang diserahkan di tempat si penjual, tetapi para pihak dapat mengatur lain (menyimpangi ketentuan KUH Perdata), dengan menentukan bahwa barang yang dibeli akan diserahkan di tempat si pembeli. Buku III KUH Perdata juga bersifat melengkapi, artinya bahwa jika para pihak tidak menentukan/ belum menentukan tempat barang tersebut akan diserahkan, dalam perjanjian jual beli itu, ketentuan mengenai penyerahan barang dalam jual beli itu akan tunduk pada KUH Perdata (KUH Perdata melengkapi ketentuan penyerahan barang yang tidak/belum diatur tersebut). Jika para pihak dalam perjanjian jual beli tidak mengatur secara rinci hak dan kewajiban mereka dalam perjanjian, hal-hal yang belum atau tidak diatur itu akan tunduk pada KUH Perdata, tetapi jika para pihak akan mengatur berbeda dengan yang sudah diatur dalam KUH Perdata, hal itu dapat dilaksanakan, dengan pembatasan sebagaimana diatur dalam Pasal 1337 KUH Perdata, yakni tidak boleh bertentangan dengan Undang-Undang, ketertiban umum, dan kesusilaan.

Buku III KUH Perdata, selain bersifat mengatur dan melengkapi, juga memuat ketentuan yang bersifat memaksa. Salah satu ketentuan yang bersifat memaksa itu adalah Pasal 1320 KUH Perdata mengenai syarat sahnya perjanjian. Para pihak tidak dapat mengesampingkan syarat sahnya perjanjian yang telah diatur dalam Pasal 1320 KUH Perdata. Para pihak mau tidak mau harus tunduk pada ketentuan Pasal 1320 KUH Perdata. Konsekuensi hukumnya adalah, jika pasal tersebut dilanggar, perjanjian itu dapat dibatalkan (apabila tidak memenuhi syarat subyektifnya, yakni kesepakatan dan kecakapan) dan perjanjian itu batal demi hukum (dianggap perjanjian tersebut tidak pernah ada), apabila tidak memenuhi syarat obyektifnya, yakni obyeknya tertentu dan causanya tidak halal (bertentangan dengan UU, kesusilaan, dan ketertiban umum). 
Suatu perjanjian untuk dapat dikatakan sah didasarkan pada terpenuhinya syarat sahnya perjanjian sebagaimana diatur dalam Pasal 1320 KUH Perdata. Tidak ditempelnya materai, tidak menyebabkan tidak sahnya perjanjian. Fungsi pemateraian dalam suatu perjanjian, merupakan perintah undang-undang tentang materai. Selain itu, pemateraian dalam suatu perjanjian, dimaksudkan agar surat tersebut (perjanjian) dapat digunakan sebagai alat bukti di pengadilan jika terjadi perselisihan. Namun, apabila suatu perjanjian tidak ditempeli materai, surat perjanjian itu dapat digunakan sebagai alat bukti, dengan terlebih dahulu melakukan pematerain di kantor pos.

Perjanjian yang dituangkan dalam suatu akta (tertulis) pada dasarnya dapat dibuat secara di bawah tangan atau dibuat secara notariil sehingga tidak ada kewajiban bagi para pihak untuk membuat suatu perjanjian yang harus dibuat secara notariil (dibuat oleh notaris). Perbedaan antara kedua jenis perjanjian itu, terletak pada kekuatan pembuktiannya. Surat perjanjian yang dibuat secara notariil memiliki kekuatan pembuktian yang sempurna (tidak dapat disangkal oleh para pihak) sedangkan perjanjian yang dibuat secara di bawah tangan akan mempunyai kekuatan pembuktian yang sempurna jika para pihak mengakui keberadaan surat perjanjian di bawah tangan tersebut.

Penyusunan suatu kontrak jual beli pada dasarnya tidak memiliki bentuk baku yang dipakai, kecuali perjanjian yang memang sudah dibakukan dan harus melelaui pejabat yang berwenang (PPAT), misalnya perjanjian jual beli tanah. Para pihak pada dasarnnya tidak terikat pada suatu bentuk tertentu, namun para pihak harus memperhatikan kelaziman anatomi dari suatu kontrak. Anatomi suatu kontrak pada dasarnya terdiri atas judul, pembukaan, komparisi, premise, isi perjanjian, penutup, tanda tangan, saksi, dan lampiran.

Kegiatan pelatihan penyusunan kontrak jual beli itu dilanjutkan dengan pelatihan mengenai penyusunan kontrak kerjasama dalam rangka pengembangan usaha. Selain itu dilaksanakan pelatihan dan pendampingan penyusunan proposal kredit perbankan untuk meningkatkan permodalan sehingga mereka dapat mengembangkan usahanya serta kompetitif agar dapat meningkatkan perekonomian masyarakat.

\section{DAMPAK DAN MANFAAT}

Kegiatan pelatihan ini telah meningkatkan kesadaran masyarakat akan pentingnya pengetahuan tentang hukum kontrak dan penyusunan kontrak. Selain itu pelatihan ini telah meningkatkan kemampuan/ keterampilan UMKM/ masyarakat dalam hal penyusunan kontrak jual beli yang baik dan benar. Hal itu sangat penting untuk menghindari kesalahan-kesahan dalam penyusunan suatu kontrak sehingga dapat memberikan kepastian hukum bagi para pihak dalam transaksi jual beli.

\section{SIMPULAN}

Pelatihan penyusunan kontrak jual beli bagi UMKM di Desa Manggungjaya dan Desa Sukanagalih Kecamatan Rajapolah Kabupaten Tasikmalaya dilaksanakan dalam rangka meningkatkan pengetahuan dan keterampilan dalam menyusun suatu kontrak jual beli. Dengan meningkatnya pengetahuan dan keterampilan itu UMKM/masyarakat dapat menyusun kontrak jual beli dengan baik dan benar sehingga mereka dapat menghindari kesalahan-kesalahan dalam penyusunan kontrak jual beli serta memberikan kepasian hukum kepada para pihak, sehingga dapat menunjang kegiatan perekonomian masyarakat. Berdasarkan hasil pelaksanaan kegiatan pelatihan itu diperoleh saransaran yakni perlunya kegiatan pelatihan-pelatihan lanjutan yang berkaitan penyusuan kontrak-kontrak bisnis yang dilaksanakan secara berkesinambungan dan berkelanjutan serta adanya pendampingan bagi UMKM/ mayarakat dalam rangka penguatan kelembagaan $\mathrm{UMKM} /$ masyarakat dari aspek hukum.

\section{PENGHARGAAN}

Kami menghaturkan terima kasih yang sebesarbesarnya kepada Prof. Dr. Wawan Hermawan, M.S. selaku Ketua Lembaga Penelitian dan Pengabdian Kepada Masyarakat Universitas Padjadjaran. Selanjutnya kami berterima kasih banyak kepada Pemerintah Desa Manggungjaya dan Desa Sukanagalih Kecamatan Rajapolah Kabupaten Tasikmalaya yang telah memberikan sarana dan prasarana sehingga kegiatan penyuluhan itu dapat berjalan dengan lancar. Tidak lupa terima kasih kepada mahasiswa peserta KKNM yang telah membantu kelancaran kegiatan penyuluhan hukum di Desa Manggungjaya dan Desa Sukanagalih Kecamatan Rajapolah Kabupaten Tasikmalaya.

\section{DAFTAR PUSTAKA}

Frans Satrio Wicaksono, 2008. Panduan Lengkap Membuat Surat-Surat Kontrak, Jakarta: Visimedia,

Setiawan, R. 1997. Pokok-Pokok Hukum Perikatan, Bandung: Putra abardin.

Sudikno Mertokusumo, 1985. Mengenal Hukum (Suatu Pengantar), Yogyakarta: Liberty.

Subekti, 1995. Aneka Perjanjian, Bandung: Citra Aditya Bakti.

Kitab Undang-Undang Hukum Perdata

Profil Desa Manggungjaya Kecamatan Rajapolah Kabupaten Tasikmalaya Tahun 2013

Profil Desa Sukanagalih Kecamatan Rajapolah Kabupaten Tasikmalaya Tahun 2013 